\title{
A Finnic Holy Word and its Subsequent History
}

\author{
By MaUno Koski
}

1

This article concentrates on a specific ancient holy word in Finnic and its subsequent development. ${ }^{1}$ The word in question is hiisi. Inflection contains a strong vowel stem (basic phonological form) in hiitet, a weak vowel stem in hiibet, a consonant stem in hiitt, e.g. Finnish hiisi, illative sing. hiiteen, genitive sing. hiiden, partitive sing. hiittä; Estonian (h)iis, genitive sing. (h)iie. Estonian and Finnish, particularly western Finnish dialects, allow us to conclude that the primary sense of the word, at least comparatively speaking, is 'cult place', or possibly - at an earlier stage - even 'burial place'. The sporadic appearance of $h i i(t) t a$ in Finnish and Estonian place names and folklore is clearly a secondary phenomenon (see Koski 1967-70, 2, 234 ff.). Labial vowel derivatives are Estonian hiid (genitive sing. hiiu), and Finnish, Karelian and Ingrian hiito ( hiitto) and hitto, all of which suggest their origin in Finnic *hiito $(i)$. These were originally possessive derivatives signifying a relationship to the concept of 'hiisi' in its broadest sense. The derivative hittunen, 'ghost, spirit of the dead', appears in central Ostrobothnian dialects. A number of place names indicate that, alongside the inflection model hiisi: hiite+, there existed a non-assibilated type hiiti: hiite+/ iiiti. $^{2}$

1 This article is largely based on my earlier research work (Koski 1967-70; see also Koski 1977), but I have also included certain other data published subsequently. I have decided to take the subject up here because my previous study has only appeared in Finnish, apart from a short paper in English on the theoretical methodology of my work, semantic component analysis. I have omitted from this article the description of source material, details of analysis results, and references to other literature, except for a few noteworthy instances. All of this may be found in earlier work (Koski 1967-70). This article includes a mere selection of examples. My research uses a philological, rather than a comparative religious, approach.

2 Examples of the non-assibilated type are as follows: Estonian: $(H)$ iid: gen. $(H)$ iie (cult places, two in Saaremaa, two in Mihkli, Pärnumaa), (H)ïtaugu (in Läänemaa), 
In the northern Estonian dialect regions the occurrence of hiis as an element of place names is concentrated in the villages which sprang up in the Iron Age or right at the beginning of the Middle Ages (for a detailed account of the connection between the distribution of these names and the historical demography of the villages see Koski 1967-70, 1, 86-92). In the southern section of the northern Estonian dialect areas (south of the line which stretches from Pärnu to Narva), the area between the Gulf of Riga and Suure-Jaani remained largely uninhabited during the prehistoric period, and the population which settled to the north and northwest of Lake Peipsi came from the east and was ethnically different. These areas contain very few sites which

(H)iitjärv (in Virumaa); hiid 'place of sacrifice' has also been documented in Mihkli (Saareste 1959, 1924). Likevise Iis = Iid (both pluralis in Iied) appears in the manuscript of Vesting's dictionary dating from the beginning of the eighteenth century. - Finnish: Hìtilä (in Southwest Häme); "Hiidilä" 1540, "Kylänhidi" eighteenth century (usually Kylänhissi) in Southwest Finland; Hiztlampi (in the Savo dialect section of Päijät-Häme); Hiitharju and Hiitsaar(i) = Hizdensaari (in the central area of the Karelian Isthmus). - Central Vepsian: Hit'ar' (Nissilä 1967,

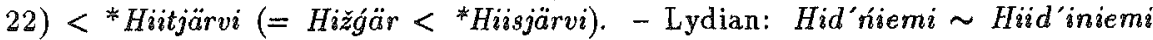
(Nissilä 1967, 21); Гит-наволок in 1496 in Sungu which belongs to the area of Southern Karelian, (PK, 6), earlier evidently a Lydian area (see Nissilä 1967, 9). - Vepsian-Karelian substratum: represented by place names in the Archangel province (oblast) of Northern Russia. These contain elements which belong to he hiisi word group. Word initial $\mathrm{X}_{\mathrm{ML}} / \mathrm{X}_{\mathrm{XT}}$ is the most common among them. There are three single morpheme names in $\mathrm{X}_{\text {ид }}$, and $\mathrm{X}_{\text {ита. }}$. Compound names include Xиднема (*hitniemi/-neemi), or Xитнемa, and in conjunction with Russian final elements, Хидгора (2), Хидозеро and $\mathrm{X}_{\text {итозеро. Names which suggest }}$ an initial element Hiss, such as Хижнема, occur in only four places, and three of these are located in the Onega district (raion). Matveyev 1976.

These elements of the language substratum are comparable to the apocope which occurs particularly in Lydian, but also in Finnish and Estonian, in the qualifying element Hiit, which represents a nominative, as opposed to a genitive, in the formation of compound words. This reveals the same structural model which exists in almost all Karelian, Lydian and Vepsian Hïis (Hiiž, Hiiš etc.) elements. There is thus no reason to assume that this is evidence of a Lydian or Vepsian genitive form lacking consonant gradation, ${ }^{*} h i(i)$ den $\left(<^{*}\right.$ hiiten), which then, as it entered Russian, lost not only its final $n$ (which is possible in the initial elements of compound words in Lydian and Vepsian), but also the e preceding the $n$. One variant of the hiiti model can be found among the Finnish dialects of upper Satakunta: i-stem Hiitti. This type of geminate also provides the structural basis for the place name and derivative Hiittinen, found among the more southern of the western Finnish dialects. Similarly, the forms Hiitio/Hiitiä/Hiittiö appear as names in southern areas, as does Hiisiö in southeast Häme. 
were called hiis. However, even in the parts which were densely populated during prehistoric times, notably the region which comprises the former provinces of Vaiga, Võhu, and Nurmekund, names featuring hiis are much less widespread than in the northern section. During the thirteenth century Hiiumaa (Dagö) was still a possession of the northern villages of Saaremaa (Ösel) lacking in fixed settlements, but the eastern part of the island was already functioning as a harbour during the Viking period. It is on this island that the most significant hiis site is to be found. According to popular belief people even came from the mainland to use this site for their sacrificial rites, and it is understood to have given Hiiumaa its name. Names of this type are otherwise relatively scarce in Saaremaa. This is partly due to the scarcity of settlements, but also due to the fact that here the "hiis" or cult place functioned for several villages, while on the mainland it was quite common for every village to have its own "hiis".

Hiis can hardly be an original lexical feature of southern Estonian, which developed from a separate dialect of late Proto-Finnic. The prehistoric culture of this area was also different from that of the northern Estonian area. Hiis clearly appears with less frequency in the place names of this region than in those of the ancient inhabited regions of Northern Estonia. A number of the names are habitation names (names of houses), which could easily have been transmitted from Northern Estonia, even at quite a late stage. In certain cases the source materials do not make it clear whether the notation is that of a proper place name or of an informant's nominal designation in a written language which was based on northern Estonian dialects. ${ }^{3}$ It is also worth noting that all incidence of hiis in Old Estonian and in early lexica demonstrates an origin in northern Estonian. The word hiis has not been discovered in a single ancient written source based on southern Estonian.

In the Finnish language region hiisi appears as an element in place names in over 230 villages established by the end of the thirteenth century, and at least a majority of these must have existed since prehistoric times. It appears in place names of 130 villages dating from the Middle Ages, chiefly the fourteenth and fifteenth centuries,

3 Data illustrating the structure of the names and the cult traditions associated with them are the same in both southern and northern Estonian. Examples of this are Hiiemägi ('the hill of h.'), as well as compound words like hiiepuu ('the tree of h.') and hiietamn ('the oak of h.'), which refer to sacral trees, and more often resemple words of common usage than proper nouns. Names of this type otherwise only occur in Northern Estonia and Finland. 
and in place names of only 85 villages dating from a later period. There are absolutely no place names containing the element hiisi in most of the areas where present day habitation goes back uninterrupted only as far as the modern era. In many regions, especially in Southwest Finland and Häme, hiisi ceases to occur as an element in place names in areas populated after the fourteenth century, at least in the sense of cult place. Some places have adopted the name on the basis of later meanings of the word in various parts of Finland.

The distribution of the nominal element hiisi in the eastern Finnic languages illustrates that the word was probably known in the cultural centre which existed near the southeast shore of Lake Ladoga between 800 and 1100, and which is hypothetically designated Ancient Karelia. This centre expanded in various directions. It first reached the Neva region in the west, spreading to the western and central parts of the Isthmus, and then further on to Ingria. (The area stretching from the Isthmus to the western parts of Ingria represents the Ingrian language region.) The centre also reached the northwest shore of Lake Ladoga, which had been a western Finnish migrant area since the eighth century, and which established itself as a new centre of expansion. Southern Savo consequently became populated towards the end of the prehistoric period, as did the north side of Lake Ladoga (both were Finnish Savo dialect areas at that stage). In addition, expansion reached at least as far as parts of the isthmus between Lake Ladoga and Lake Onega, an area which has also been inhabited by the Veps (see e.g. Itkonen 1971). Prehistoric settlements spread as far as the northern limit of Lake Onega covering the isthmus and the region to the northwest of it. This area contains approximately 30 place names which include the element hiisi, in the present day regions of Lydian, Olonets and southern Karelian dialects. However, none occur in the northern Karelian dialect region where settlements had evidently stemmed from the direction of Olonets as early as prehistoric times, and from Finland later, in the modern era. Neither do any occur among the migrant settlements which had evolved at the end of the sixteenth and during the seventeenth centuries, in and around Tihvin, the Valdai Hills, and Tver. The word does not appear in these areas as a common noun, nor does it in the Vepsian area, where two place names have been recorded, one in northern Vepsian (on the shore of Lake Onega), and the other in central Vepsian in Simgäar. There is also one other uncertain reference dating from 1496 in the area of central Vepsian. There is no such documentation in southern Vepsian. The Russian language of the Northern Russian province 
of Archangel includes 23 place names with hiisi as a component, all situated around the Onega and Dvina rivers and their tributaries (Matveyev 1976). These names are structurally similar to those of the Vepsian, Lydian, Olonets and southern Karelian language regions. The people, the "zavoločeskaya čud", of whose language these names represent a substratum, populated this area between 800 and 1200 at least, during the rise of "Bjarmia". We may conclude that this people consisted of Veps from the central and northern Vepsian regions, and of the inhabitants of the isthmus between Ladoga and Lake Onega, whose language contains features of Karelian and Vepsian (Lydian).

The relatively early appearance of the word in (western) Votian is demonstrated by the place names Id'jeemäči and Iisi. ${ }^{4}$ Amongst the Ingrian speaking peoples in Ingria, hiisi appears in the name of a cult place in one village. As a common noun, hiisi does not appear in either Ingrian or Votian.

The word hiisi is not known in Livonian. Since it is not known in southern Vepsian either, and only occurs as a secondary feature in Estonian, we may determine the centres of its usage in the Finnish language regions at the end of prehistory as follows: 1) Western and Northern Estonia, 2) the Iron Age settlement areas of Southwest Finland, 3) the centre around Ladoga known as Ancient Karelia, as well as those areas linked to it i.e. the centre northwest of Ladoga, the region between Lake Ladoga and Lake Onega, as well as their areas of expansion. The nominal feature has evidently also been adopted from the Karelian centre southeast of Ladoga into northern and central Vepsian. The rare incidence of the name in comparison to its appearance in Karelian or Lydian indicates that the word was not productive in Vepsian. The names occurring in Votian may have originated in the Northern Estonian centre, if we accept that Votian evolved in the first millenium AD from Estonian and Ancient eastern Finnic (see Laanest 1982).

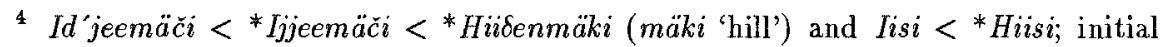
$h>\emptyset$ confirms that the names are not loans from Ingrian or Finnish. This list also includes the name Hijjeenukka, in the village of Kukkosi (VKM 1980; $h>\emptyset$ does not occur in the Kukkosi dialect but on the other hand this dialect does contain many Ingrian characteristics). 
Conclusive evidence of the use of the word hiisi in the sense of 'cult place' has only been established in Estonian and Finnish. Estonian has preserved this definition in both written and oral tradition, while Finnish seems to have lost this meaning since the beginning of modern history. The word still appears in the sense of cult place in Mikael Agricola's translation of the Bible, as well as in the margin notes, dating from 1551, but no longer in the 1642 translation of the Bible. The word does of course occur in seventeenth to nineteenth century literature and dictionaries, but always in its other, secondary meanings. It was only in the scholarly literature at the end of the nineteenth and beginning of the twentieth centuries that the connection was made between Finnish hiisi and Estonian hiis. The word has been used to denote 'cult place' in scholarly texts since the 1930 's, after the decisive influence excercised by A. M. Tallgren's article "Hiisi ja Moisio" (Tallgren 1933). This meaning is not recognised in everyday language.

In Finland as well as in Estonia it is possible to demonstrate an earlier sacral function in places which contain hiisi as a component of their name, partly with the help of archeological discoveries, and partly with the help of oral folk tradition. Evidence of burial grounds dating from the Iron Age has been established in five sites in Southwest Finland and in eight sites in Satakunta and Häme (between Kokemäki and Sääksmäki). A number of these date from the Viking period, a number of them are older, the oldest having been in use since the third century, and in a number of them, the most recent graves date from the Merovingian period (600-800). It seems that these sites retained their sacral character even once the place no longer functioned as a burial ground, and evidently the cult was then directed at the deceased ancestors and their spirits. Naturally we can infer that the term hiisi was used to refer to these burial grounds towards the end of prehistory, but we cannot determine at which point the term first came into use. Neither can we determine whether or not at one time the term hiisi applied to all burial grounds of this type (in which case it did not always become a fixed place name). Moreover, these same areas contain several "hiisi" sites in which, according to oral tradition, an ancient burial ground was once located. This sort of information is extremely rare in other areas: in the central section of the Karelian Isthmus, Antrea (Hiidensaari Hiitsaari), and in Muhos in the district of Oulu (Hiidenlinna). The terms used for Bronze Age 
barrows, hiidenkiuas or hiidenvare, often with the first part of the word in the plural hiitten, are also linked to the concept system of the world of the dead in former times. In certain places, tradition has it that these barrows represent the graves of the former inhabitants of the area. Folk poetry also makes a physical reference to a grave in the following lines: "Minä nostan nukkuvia/ Nurmen alta nukkumasta,/ Pellon alle peitetyitä,/ Hiien alle heitetyitä,/ Tulisellen tanterellen". (I will raise the sleeping ones/ From their sleep beneath the grass,/ Under the field they lie covered,/ Under the hiisi they have been cast,/ Onto the fiery ground I lift them). The poem was recorded in Northern Savo, but it may have originated elsewhere.

Similar data have been recorded in Estonia. In Saaremaa there are five "hiis" sites which, according to archeological excavations or popular belief, once contained burial grounds. Examples of this are the middle and late Iron Age grave sites (barrows) in Kaarma and Valjala. On the Estonian mainland such sites are to be found in the following locations: Kullamaa (Iron Age) and Varbla, both in Läänemaa, Risti (Iron Age) in Harjumaa, Vändra in Pärnumaa, Lüganuse (stone grave), Haljala and Simuna (thirteenth century cemetery) in Virumaa, and Äksi and Kursi in Tartumaa. In Türi in Järvamaa one of two names given to a "hiis" site is Kalmu, meaning "graveyard (not Christian)'. In another village in Türi the "hiis" and the "kalmu" are situated next to one another. In Kunda in Viru-Nigula the village's dead were burned on Hiiemägi according to oral tradition. This may denote a Scandinavian type of funeral pyre. There is a tale associated with Hiiemägi in Päinurme in Peetri, which relates that every man had to carry a stone to the site so that the ashes of the buried soldiers or kings would not be lost. Many different tales on the theme of "hiis" burial grounds exist elsewhere too, but they are part of a later narrative tradition. In the area of southern Estonian, there are two instances of recorded data indicating that "hiis" is an ancient burial ground, in Tartu-Maarja, and in Vastseliina. ${ }^{5}$

A few of the narrative themes of Estonian folklore use hiis or the derivative Hiiela to refer to a post-mortal world or 'otherworld'. The clearest allusion to a burial place occurs in variants of the theme

5 These notations were discovered in Estonia's folklore archives, amongst the material collected in the 1930 's, and they do not necessarily reflect the meaning of the word in the local dialect. Estonia's name archives do not record a single place name containing the element hiis in either parish. Nevertheless the notations cannot be based on literary or other similar sources, in which "hiis" only signifies a cult place or a wood. 
"At mother's Grave": Käisin eile Hiielassa,/ Tunaeile Tuonelassa,/ eile eide haua peala" (Yesterday I was in Hiiela,/ in Tuonela the day before,/ at my mother's grave yesterday). The dialect of the northeast coastal region reveals a great deal of Finnish influence, such as the nominal derivative Tuonela (Otherworld, the dwelling place of the dead), but these lines of verse have not been discovered in Finnish folklore.

Generally speaking, the appearance of hiisi as an element in the names of pre-Christian burial grounds or in non-Christian ones from the Middle Ages, is a western phenomenon. In the region of the eastern Finnish dialects, there exists only one such place which popular belief maintains to be a burial ground (in Antrea, in the central section of the Karelian Isthmus). Not one burial ground of this kind is known to exist in the region of Karelian, Vepsian, and their hybrid languages (Olonets, Lydian). One documentation from an Ingrian speaking village in Ingria mentions the "hiisi" site in connection with a burial ground. No information exists concerning the function of "hiisi" sites in Votian. It is even questionable whether the early semantic content of the word hiisi in the Karelian centres of the Ladoga region was the same as that in the Estonian and Western Finnish centres. ${ }^{6}$

Estonian demonstrates unequivocally that the sense of the word is 'sacral place', and more accurately 'cult place' or 'place of sacrifice'. Data relating to several place names indicate that hiis denotes a place of sacrifice. In certain cases, sacrificial rites were still being held so recently that data concerning folk traditions collected at the turn of the century, and even within the early part of the twentieth century, describe the objects of sacrifice: food, beer, money, wool, clothes. Animal sacrifices, on the other hand, are only mentioned in a couple of instances. There are also a number of citations concerning the healing of diseases at the "hiis" site. Rites have also included bonfires and dancing.

The object of the cult has altered over the centuries. Worship of the dead, of the spirits of ancestors, represents at least one, and evidently the primary prehistoric cult. But certain features are also linked to

6 From a methodological point of view, it is essential to ask to what extent we can draw conclusions about the semantic history of the word as it occurs in place names, on the basis of the information we have to hand, that is to say information concerning 1) the places themselves, which have been so named (functions, typography; etc.), 2) the appearance of the word in certain other contexts (e.g. folklore), and 3) explicit definitions of the word in dictionaries, and other documentation which deals with the word (e.g. collections of dialect data). 
the Scandinavian cult of Thor, such as Thursday being the day of the cult, and similarly, there are features relating to the cult of St. Anthony, inspired by Catholicism (Tõnni vakk), and to the Finnish cult of Ukko on the north coast. On a secondary level, in various parts of the northern Estonian dialect region, $(h)$ iis is understood to refer to the deity (idol) or other spirit residing at the site and to whom the sacrifices were made. This sort of connotation must be interpreted as a consequence of the need to identify the receiver of the sacrifices, which suggests that the notion of the original object of the cult has become blurred or vanished altogether. ${ }^{7}$ The view of the cult as a collective group may reflect its earlier identifications with the dead (ancestors, figures from an earlier age). which has since been forgotten. The fact that it is precisely the word hiis which has been chosen as the designation may stem from situations in which the word, originally indicating place (to which the sacrifice was taken), may have been understood to refer to a being (to whom the sacrifice was taken). This kind of semantic development can also be traced elsewhere, such as in the Votyak word lud and the Cheremis word keremet. One or several wooden idols are said to have stood on a number of the "hiis" sites.

As far as Finnish is concerned, only Agricola's texts contain documented evidence of the definition 'cult place' for the term hiisi. Such biblical references do not however throw any light on the nature of the cult practised at Finnish 'hiiisi' sites. The only real information we have, therefore, is based on the data surrounding places in which hiisi appears as an element in the name. The meaning behind the designation must be sought by way of the proper noun. Archeological findings have only been able to testify to one site having been a place of sacrifice: Hiismäki in Rusko (there is also a burial ground in the area). There are references to holy places in certain eighteenth-century sources concerning the parishes of Mynämäki and Nousiainen: "Hijdenkangar" ('the heath of hiisi') and "Hitenhafwat" ('the aspens of hiisi'). Similarly, in Huittinen, there is a record from 1759 of a sacrificial fount at Hiidenkallio, and in Pyhäjärvi in the district of Oulu, P. N. Mathesius' Dissertatio geographica de Ostrobotnia, 1734 mentions "Hiidenmäki, collis, ob sacrificia, hic olim celebrata". In Savitaipale, the mid-seventeenth century manuscript of a

\footnotetext{
7 Of the thirteen references which indicate personification, the word appears as the name of the being residing at the "hiis" in the plural in ten instances (hiied), and in the singular (hiis) in only three instances. All the singular recordings were made by the same collector, Jakob Hurt, towards the end of the nineteenth century.
} 
clergyman, Mikael Heinzius, states that "Hiienmennikkö" (nowadays Hiidenmäki), a small hillock, had once been a holy birch grove. Later tradition has it that Hiidenmäki in Karkku and Hiidenlehto (lehto 'grove') were once sacrificial sites. A sacrificial fount has existed at Hiidenmäki in Pirkkala, and on the cape of Hiidennokka in Narva (Vesilahti), which is an Iron Age burial ground dating from the sixth century. Also in Kaarina near Turku, Hiisilähde is said to have been a sacrificial fount. According to one mid-nineteenth century notation there was a sacrificial tree Hiiskoivu (koivu 'birch') in Hirvensalmi. The morphosemantic structure is similar to that of compound words like hiishonka (in Rantasalmi, where it has been preserved as a component of the place name Hiishonganmäki, (honka 'pine'), and IIidenkuusi (Kiuruvesi, kuusi 'spruce'), and we can therefore assume that these have also been names of cult trees. (No other meaning is possible where hiisi is in the nominative). Like Estonian "hiis" sites, many Finnish "hiisi" sites were used for bonfires and dancing in former times. There are records of this in connection with twenty "hiisi" sites, a number of which have also been proven to be burial grounds (e.g. Hiisi in Kokemäki, Hiidennokka in Vesilahti (Fig. 1) and Hiidenniemi in Köyliö) or places of sacrifice (e.g. Hiidenmäki in Karkku, Fig. 2). A number of other burial grounds and sacrificial sites whose names do not contain the element hiisi have also functioned as locations for bonfires and dances.

It is particularly among the earliest settlement areas of Southwest Finland, Satakunta and Häme that hiisi features in the names of sacrificial sites or trees, in other words in the same areas where it features in the names of burial grounds. It also appears, however, in the eastern dialect regions which were populated during prehistory and the Middle Ages, although not east of the border established by the Treaty of Nöteborg (Pähkinäsaari) in 1323 (except for Pyhäjärvi, which is further north in the district of Oulu). A number of sites used for bonfires and dancing are located in the eastern dialect regions of the central section of the Isthmus, the ancient settlement areas of Savo, and the area north of Ladoga east of the 1323 border, as well as in Satakunta, Häme, and south of Lake Päijänne, although from the latter there are no surviving records of them having been used as places of sacrifice.

The presence of a sacrificial site has only been established in one of the Ingrian speaking villages of Ingria: Hiite in Kallivieri (also a burial ground). Kallivieri is situated right in the western part of Ingria and once belonged to Estonia. This may therefore indicate a 


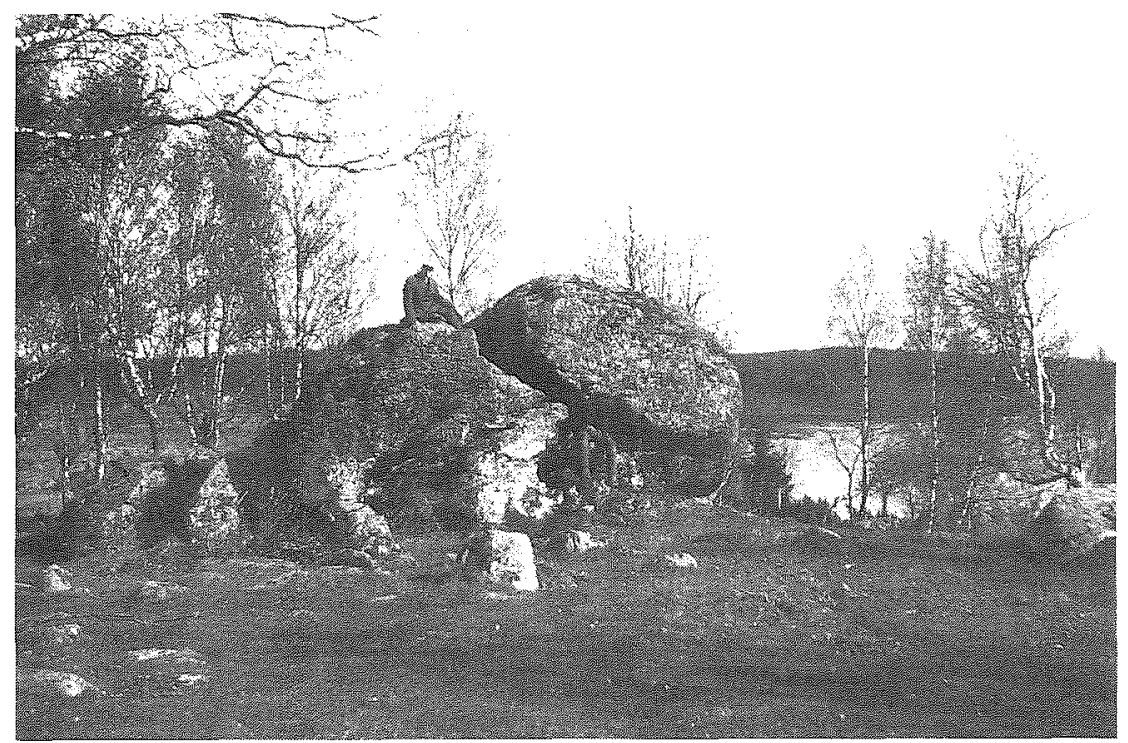

Fig. 1. The plateau of cape Hiidennokka in Vesilahti, Narva, in Häme (Finland) is a bonfire site. Photo: National Museum, Helsinki. There is a cemetery (four barrows) from the end of the sixth century and a sacrificial fount on the same site. A plateau and stoniness are the most common features of "Hiisi" sites.

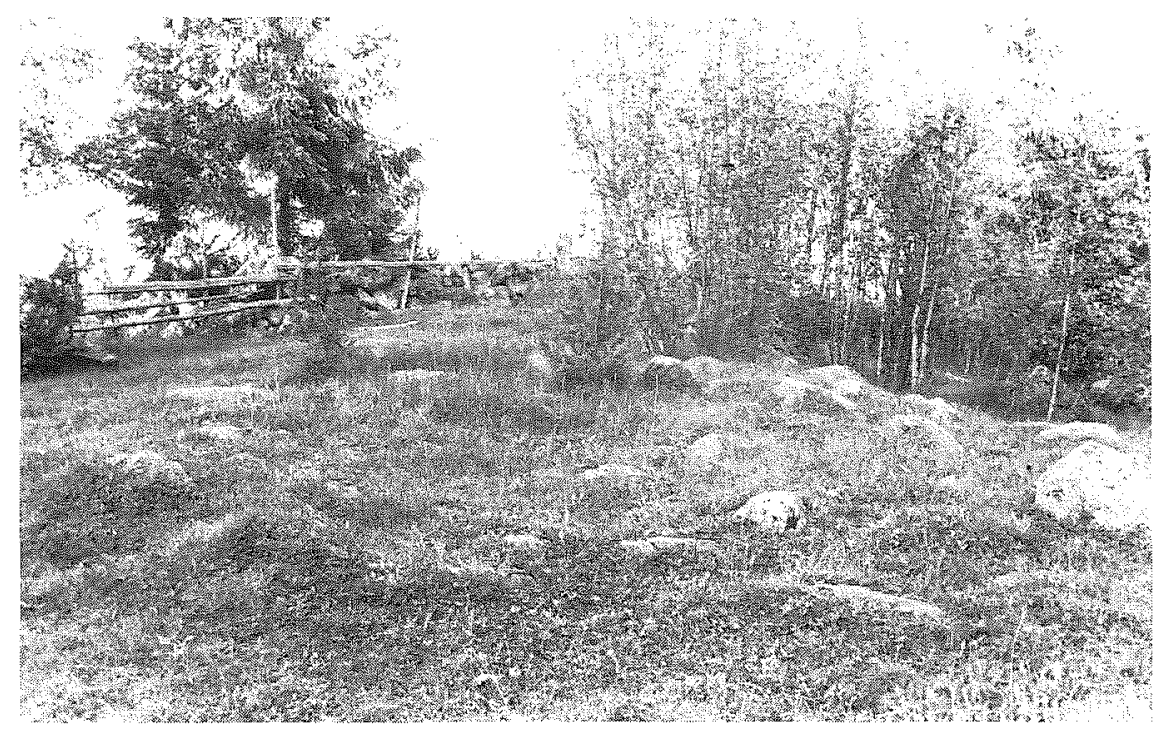

Fig. 2. Hiidenmäki in Karkku, Kojola, in Satakunta (Finland). Photo: National Museum, Helsinki. The stones are arranged to form an enclosed area and set in a grassy plot which has been tramped flat. This was a site for ritual bonfires and, according to folk tradition, it was also used for sacrifices. 
tradition carried over from Estonia, but on the other hand, the village in question was once Votian.

The "hiisi" sites in Western Finland, around Viipuri (Viborg), and in the section of the Isthmus which lies west of the 1323 border, are set well within the villages established during prehistory and the early Middle Ages, relatively close to the dwellings, but after the fourteenth century they were situated beyond the areas of habitation, in the outlying country. This distribution seems to have resulted from the church's attempts to suppress pagan cult practices. Among the older settlements, this is apparently how cult places came to be located in the hinterland. Among newer settlements, cult places were established in the hinterland right from the start. This process also took place to a certain extent in Savo, where several "hiisi" sites are to be found lying off the routes through old hunting grounds. This shift in the location of cult places may be ascertained partly from the topography of the sites.

At the beginning of the thirteenth century the church took over the former cult places in Finland, as the 1229 bull of Pope Gregory IX demonstrates: "luci et delubra, deputata olim ritibus paganorum" were surrendered to the church. Another papal edict from 1232 mentions "terram de Maska que dicitur Lunda", which has been shown to be a reference to the "hiisi" site in the village of Villilä in Masku (Fig. 3). Like many such sites in Southwest Finland, this belonged to the church during the Middle Ages. Other examples of this are to be found in Kalanti (Kylänhiisi 'the hiisi of the village'), and in Lieto, Piikkiö and Pertteli (Hiisi).

Churches or chapels were erected on a number of the "hiisi" sites. Similar evidence of the church's takeover of "hiisi" sites can also be found elsewhere. However, during the Middle Ages, and in some places well into the modern era, the church's influence on the people remained superficial, and many pagan or semi-pagan rites were practised, particularly in remote areas, right up to the nineteenth century. There are seventeenth and eighteenth century literary references to the pagan cult places of the Finns, and when the parish of Puumala was established in Southern Savo in the seventeenth century, the parsonage occupied the sacral "hiisi" site (Hiisimäki $\sim$ Hiidenvuori) and the church was erected alonside it. In the area east of the 1323 border, which belonged to the sphere of the Orthodox church, the former sacral customs continued to be observed without too much interference. It was only during the sixteenth century that attempts were made to eradicate pagan cult places, but their obliteration was 


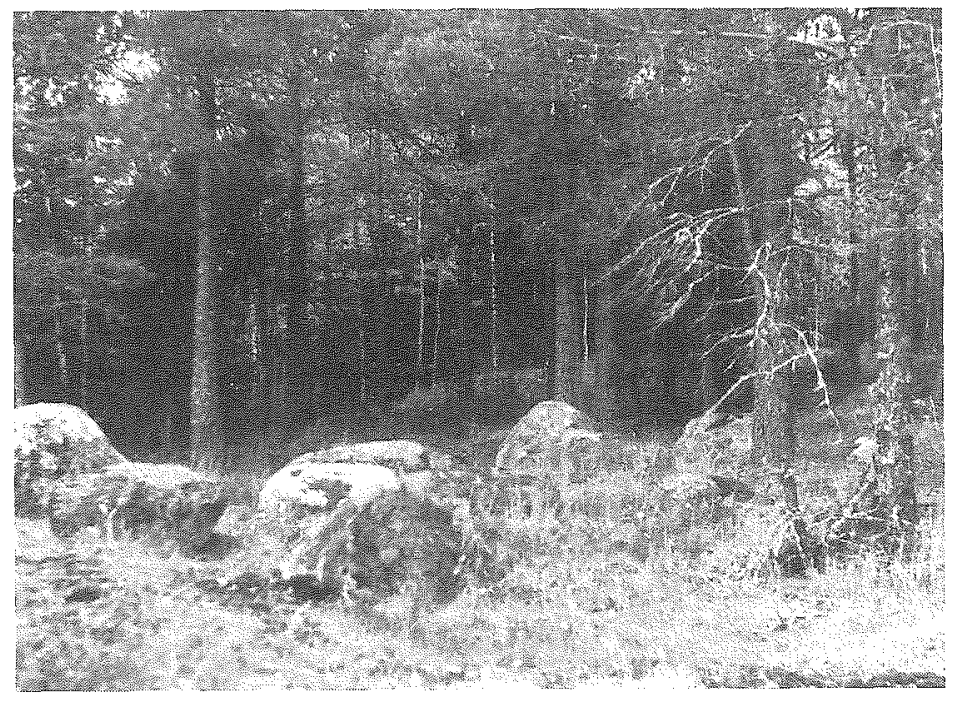

Fig. 3. The plateau with circular stone formation on the hill Hiidenpellonmäki in Masku, Villilä (Finland) may have been the nucleus of the "Lunda" mentioned by the Pope in 1232. Author's photo.

never completely successful. In this sense, place names in Orthodox areas might easily have preserved manifest evidence of a word meaning "cult place', but the cult's dependence on specific "holy places" in eastern Orthodox areas seems to have differed from the situation in, for example, Estonia. The cult of the dead was held at graveyards which were still in use, and other cults, especially fixed seasonal rites which involved the whole village or a large group, were just as readily practised in any large yard or in front of the village chapel (tsasouna), as at a given natural site (Harva 1948, 503-509; Haavio 1959, 142; see also Haavio 1961). Since, in the Ladoga region and in Ingria, the topographic characteristics of places whose names contain the component hiisi are largely the same as those in the Western Finnic regions (land elevation), there is good reason to suppose that they were also named according to the same principle, at least in the beginning. In the lexica of the languages in question, however, the word hiisi does not seem to have meant 'non-Christian cult place' during the Christian era. We may at least presume that in Orthodox Karelia and in Ingria there existed no pragmatic necessity for such a definition, insofar as any word might have applied in this function.

Not all the "hiis" sites of the Finnic language region display the same topographic features, but it is possible to outline a few prototypes. 
One type is a deciduous wood, a grove, or less frequently, a coniferous wood, especially one situated on a smallish knoll. The grove is a very common type in Estonia, as both place names and definitions in nominal descriptions demonstrate. The grove has always figured far more rarely in Finland than it has in Estonia. The prehistoric settlement areas of Western Finland show evidence of only a few groves. In several cases the authenticated Iron Age burial grounds do not look like groves, but the wood characteristic of the grove may have disappeared over the centuries. The grove-type also occurs among the eastern dialect regions around the Gulf of Finland all the way to the central area of the Karelian Isthmus, in Southern Savo, though less frequently, and finally also sporadically east of the 1323 border, near the western and northern shores of Lake Ladoga.

The second prototype is represented by a shallow, marshy meadow or marshy dale (Fig. 4). This occurs, above all, in the western parts of Estonia, but also to a certain extent further east, among the northern centres of expansion as well as in the western parts of Ingria. This type also contains grove-like features.

The third prototype is an elevated site (Fig. 5), in Finland often a rocky mound or otherwise a very stony hill (boulder soil), almost a mount (Fig. 6). This type is very rare in Estonia, where the land is mostly flat. However it does occur on the northeast shore, which displays manifest Finnish influence in both language and culture. Approximately thirty high, rock-like "hiisi" sites are to be found in Western Finland, but this type really dominates the whole of Eastern Finland from the northwest shore of Lake Ladoga. ${ }^{8}$

\footnotetext{
8 The predominance of the grove in Estonia, and the relative frequency of both grove and mount in Finland, is partly revealed by the fact that Agricola used the word hiisi to refer to a sacrificial hill (Latin excelsum, German Höhe) as well as a holy grove (Latin lucus, German Hain), but in the Estonian translation hiis only appears in the meaning 'holy grove' when it is a place reference. In the Estonian translation of the Bible, first published in 1739 , the hebrew word ašera is translated in all its functions by the word hiis. Ašera refers to the goddess of fertility, as well as to the symbol (idol, totem, tree trunk) and the place of worship associated with her. The corresponding word in the Latin translations is lucus, and in the German Hain, which also appear in all functions. There are thus certain contexts in the Bible where hiis must be interpreted as a reference to a being. In its usage of this word for the personification of a deity, the Estonian version partly follows the examples set by the Latin and German translations. However, this usage may also be evidence of the fact that, by the eighteenth century, a secondary understanding of the term hiisi had already emerged, one denoting a deity or, as we can see in later folk tradition, a collective concept of deities hiied.
} 


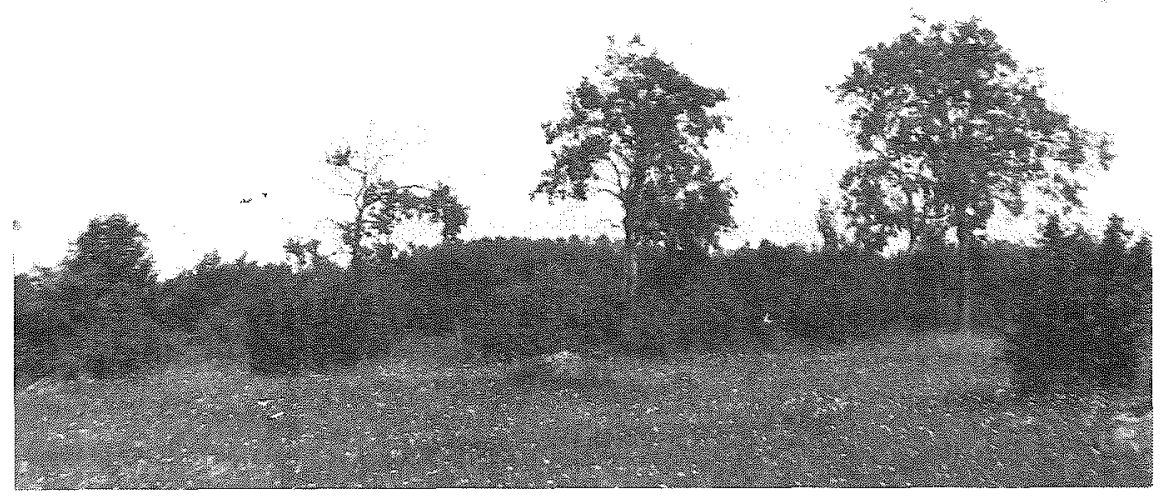

Fig. 4. Hiie mets in Lihula, Sipa (Estonia), is a small copse on marshy ground. Photo: Estonian Academy of Sciences, Museum of Literature, Tartu.

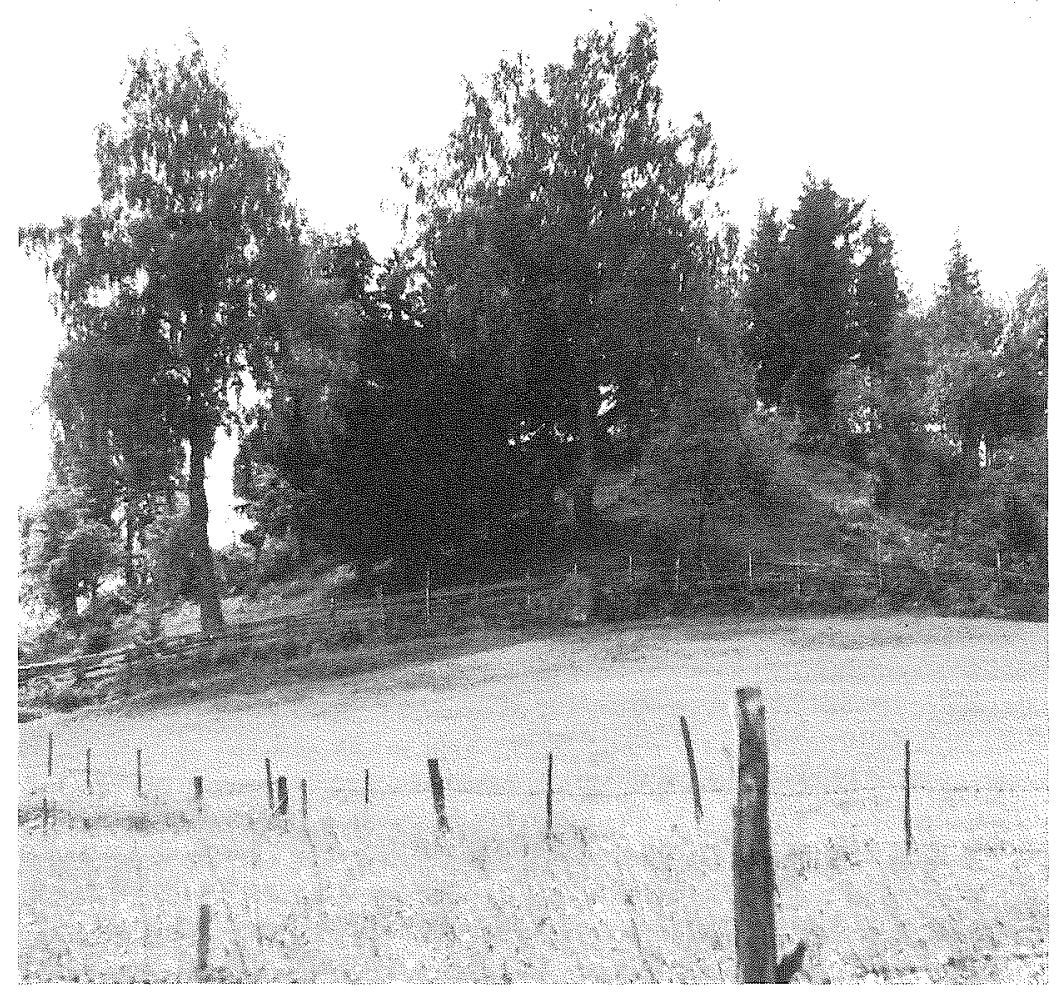

Fig. 5. The gravel mound Hiidenmäki in Asikkala, Kurhila, is a typical "hiisi" site in South-east Häme. Author's photo. 


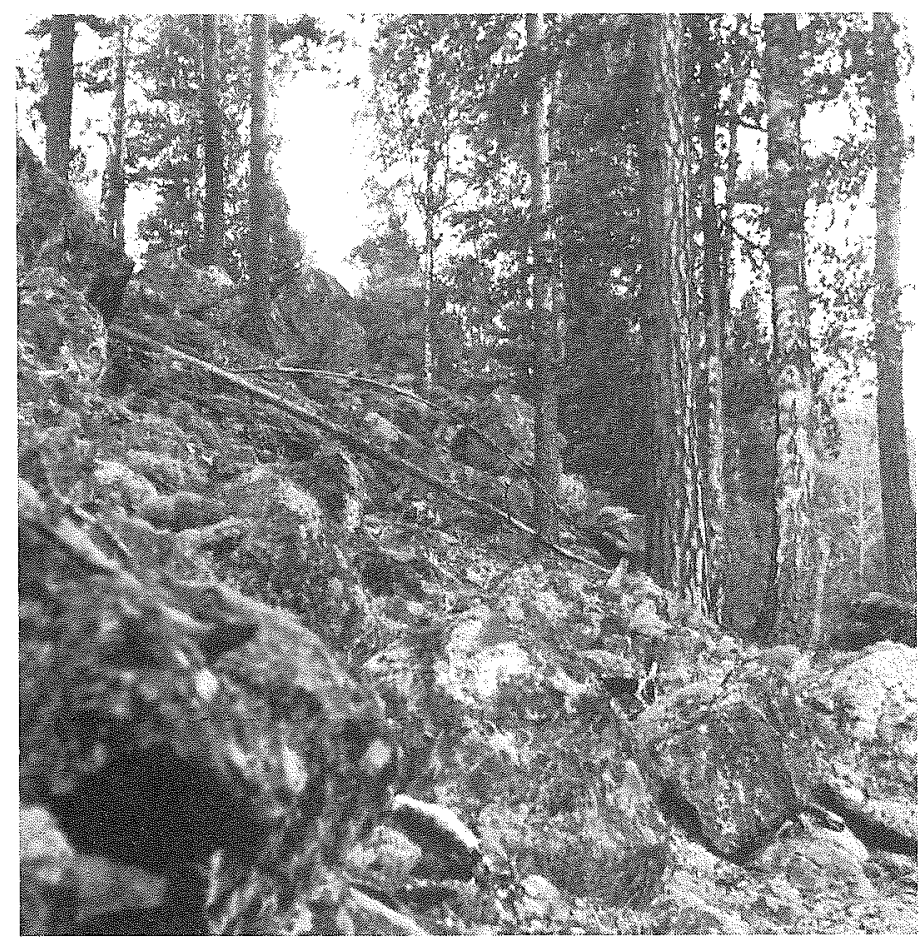

Fig. 6. A slope of bulder soil in Hiidenkallio in Hauho-Tuulos (Häme). Author's photo.

Stoniness is a feature of several "hiisi" sites in Estonia and Finland which are characterised by a stone construction of some kind, sometimes a lowish stone mound (Figs 7 and 8), or otherwise a circular formation often with the addition of one stone larger than the rest; another common feature is a large stone (a glacial boulder) or several relatively large stones (Figs 1,9 and 10). Both grove and mount types are often characterised by a clearing, a plateau which was apparently the sacral focus of the cult place, as well as the setting for the stone arrangements.

When the institution of the "hiisi" in Southern Finland shifted to the hinterland soon after the beginning of the Middle Ages, new sites had to be chosen according to some recognisable criteria. One such criterion was the stone quality of the place. Even among early settlements certain "hiisi" sites were high, craggy rocks with one sheer face. Another model was a stone construction or some stone formation in general. In the hinterland the tumuli (hiidenkiuas), Bronze 


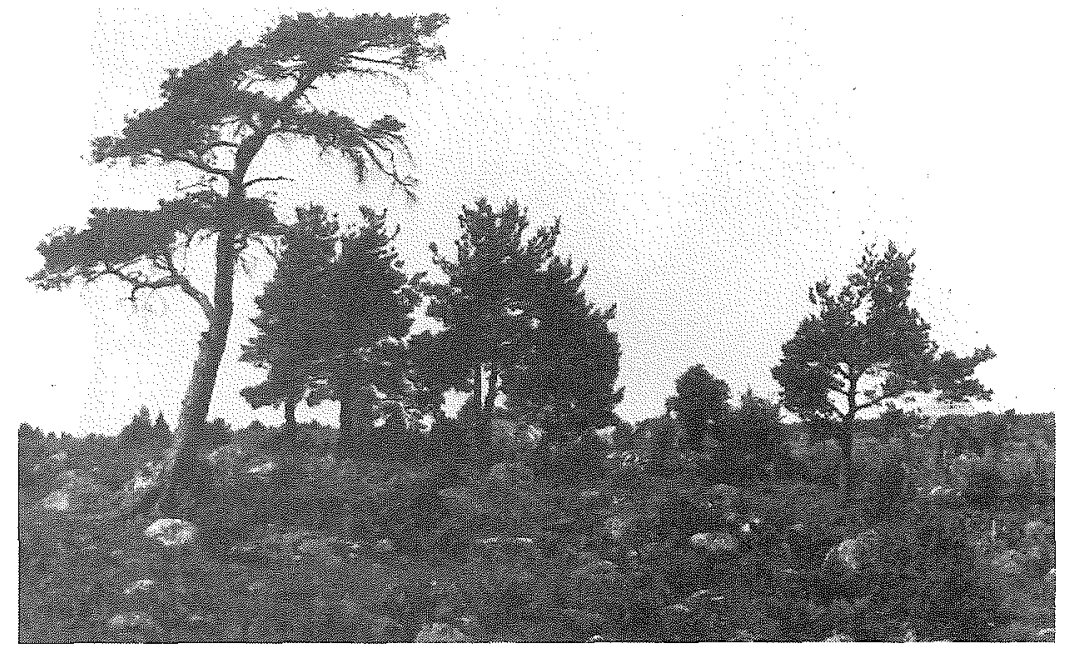

Fig. 7. Hiie pank in Varbla, Allika (Estonia). Photo: Estonian Academy of Sciences, Museum of Literature, Tartu. Many of the "hiis" sites on the western and northern parts of the Estonian mainland are gentle mounds within level fields, and they are characterised by their stone quality.

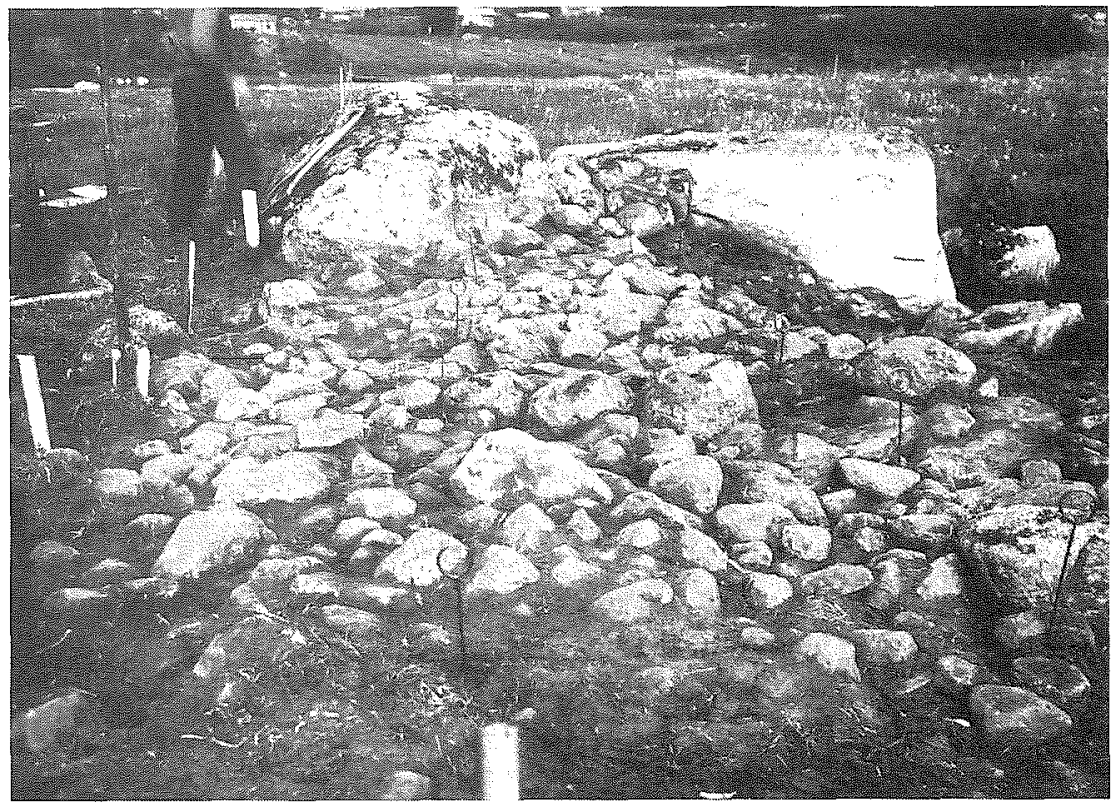

Fig. 8. The stony mounds of the burial ground (from the Migratory and Merovingian periods) exposed in Hizdentöykkä in Huittinen, Loima (Satakunta). Photo: National Museum, Helsinki. 


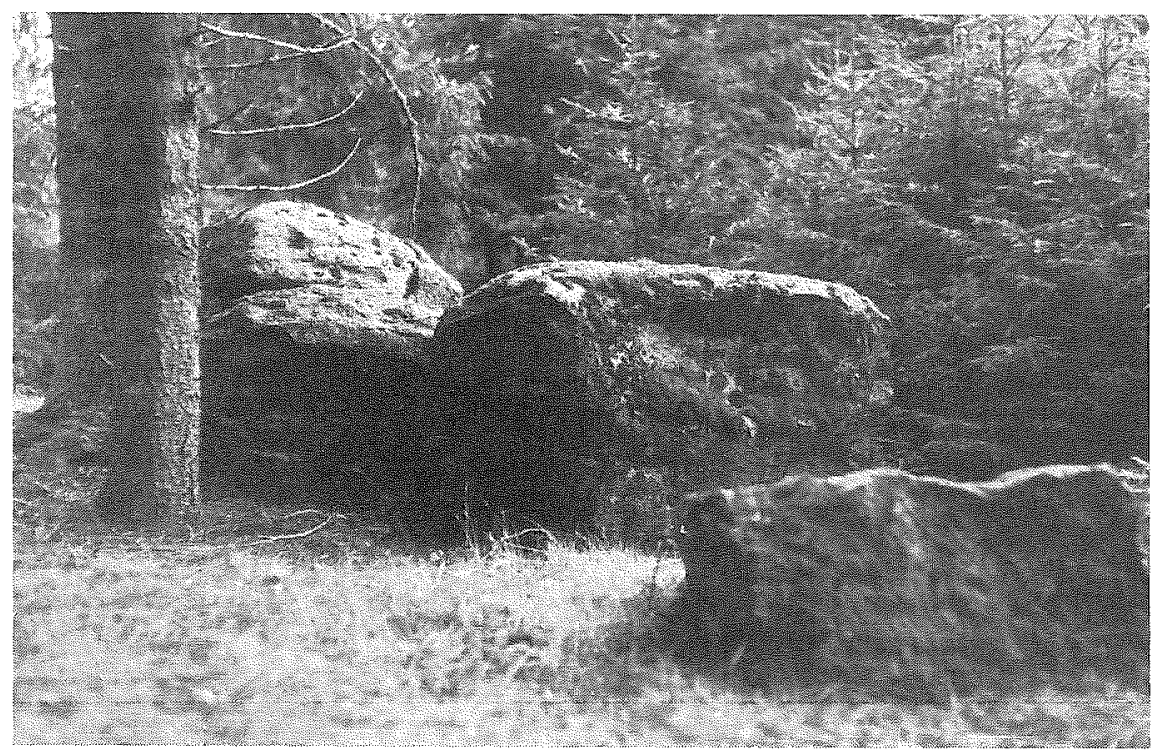

Fig. 9. Stones (hiiekivi on the hill Hiiemägi in Kullamaa, Maidla (Estonia). Photo: Estonian Academy of Sciences, Museum of Literature, Tartu.

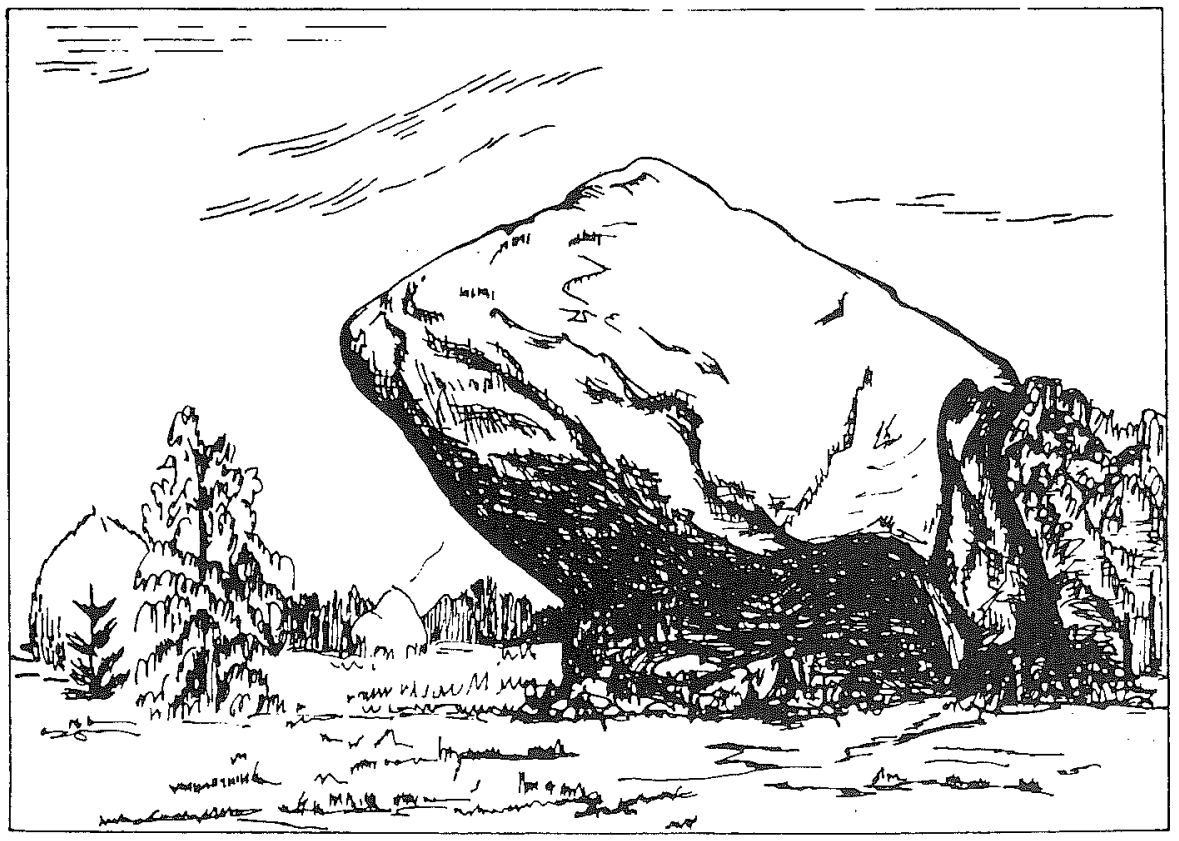

Fig. 10. Hiiepõld ('the field of hiis') in Valjala, Väkrä (Estonia). After Remmel 1962. Healing arts were practised at the foot of the stone (hiiekivi) and evil spirits were believed to live beneath it. 
Age barrows set high up on rocks, fulfilled this criterion. This is why, in Varsinais-Suomi, Satakunta and Häme, in the surrounding countryside of villages which sprang up after the beginning of the Middle Ages and sometimes of even older ones, the hiisi component appears in the names of craggy, mountainous rocks or places with Bronze Age barrows or other similar stone formations. Examples of this are Hiidenvuori, Hiidenkallio, Hiidenniemi (often in the plural Hiitten-, which may be of later origin). We can explain certain names and nominal designations in hiidenkivi (kivi 'stone') in the same way as they may have been inspired by the large stones which stood at several of the old "hiisi" sites. Nevertheless, not all of the place names beginning with the element Hiiden/Hiitten can possibly reveal a cult place. In certain cases the name has undoubtedly originated in a secondary meaning.

Often several place names containing the hiisi component apply to the same "hiisi" site, such as in Ansekylä in Saaremaa, where Iide $m a ̈ g i$ is the name of a high ridge, next to which is a massive boulder called Iide kivi, and a marshy spot with a few trees called Iis. The independent nominative form indicates that these names refer to a genuine "hiis" site, but on the other hand we cannot be sure whether the stone and the hill are parts of the same sacral area. Both Estonia and Finland show evidence of "hiisi" sites with dual focus, in the sense that the sacral nucleus, the 'altar', existed both at the top and at the foot of the hill, for example a stone construction at the summit and a sacrificial fount at the bottom.

Names in which the hiisi element precedes a word meaning a lake, pond, or other water formation, occur particularly in the eastern Finnish dialect regions, as well as in the regions of Karelian, Olonets, Lydian, and Vepsian. A number of these appear together with a landbased place name e.g. the lake is called Hiidenjärvi and on its shore lies Hiidenmäki (as in Kirvu and Antrea) or Hiidenvuori (as in Sääminki and Hirvensalmi), but often Hiidenjärvi, Hiisjärvi, Hiislampi, Hiidenlampi or Hiidenlahti appear independently (järvi 'lake', lampi 'pond', lahti 'bay'). In the Finnish language region there are approximately twenty instances of water names of this kind appearing independently. In the regions of Karelian, Olonets, Lydian and Vepsian they are rather more frequent: over half of all place names containing the element hiisi, including both those confirmed in Vepsian (Hisd'ärvut, d'ärvut 'pond', and Hizgäär Hit'ar' < -järvi). In the substratum nomenclature of the zavoločeskaya čud' there are also two independent lake names, Хитозеро and Хидозеро. This relatively large number 
of waternames within the eastern Finnic language region does not however prove that the point of reference for the word hiisi must have been the expance of water. It is at least as plausible, and possibly more so, that it was on the shore that the real point of reference was to be found, although we cannot be certain about the precise meaning of the word. For example in Tšelmuša in Poventsa there is a bay Hiislahti, Хиж-Гува on a Russian map, but a notation from 1563 also mentions Xü-Гора (a vast, inhabited mountain region). Since many of the lakes called Hiisjärvi are very extensive, often several kilometres in length, their naming must somehow have had a broader significance e.g. it was known in more than one village. In addition, most of the places called Hiisivuori or Hiisivaara are conspicuously high, massive elevations; not all of them however are on the actual lakeside, e.g. Hiisivaara near Porajärvi and Soutjärvi, the highest mountain in the area, is in the middle of a forest, $2 \mathrm{~km}$ from the surrounding lakes at the nearest.

Apart from two habitation names in Finland, there are no instances of simple word names in Hiisi in the regions of eastern Finnish dialects, Karelian, Lydian and Vepsian. ${ }^{9}$ The regions inhabited by the zavoločeskaya čud' include three places called $\mathrm{Xnz}_{\text {ng }}$ of which two are meadows (Kargopol', Onega) and the third is a rock, on which stands a "huge, terrible stone" (Onega). This region also contains a meadow called Хита, which is connected with a brook called Xитскои and with a large stone, Хитскои Камень (cf. "hiidenkivi" - 'the stone of hiisi" - in Finnish and Estonian) (Onega). Fields or meadows also bear the names Хиднема and Хищ наволок (Onega), and one place called Хижнема (< Hiisniemi) (Onega) has been recorded as a copse. In these same areas there are names of mountainous places like Хидгора (ropa Russian 'mountain') "evil, awkward place" (Onega, also Pinega) and Хижгора (where there is a dense, dark pine forest which resembles countless "Devil Mountains"; nearby is a lake inlet Хижлахта, and the lake itself is called Xижозеро; Kargopol'). (Matveyev 1976.)

In general the landscape features of the places whose names contain the element hiisi among the regions inhabited by the zavoločeskaya

9 The house Hiisi in Lummäki is in a village established after the introduction of the new land division regulations of the second half of the eighteenth century, but the surrounding villages date from the Middle Ages. Hiisi in Sotkamo, nowadays Hiidenkylä, is in the outlying country of a seventeenth century settlement, near a lake by the name of Hiidenjürvi, on the shore of which stretches a high, rocky mount by the name of Hiisivaara $\sim$ Hiidenvuori. Neither place is situated within the old Orthodox area. 
čud', resemble those in Estonia and Finland, west of the 1323 border, more than those in the Karelian, Lydian and Vepsian areas of Lake Ladoga and Lake Onega. Since we can show that these crud' originally came from the latter areas and spoke their languages, the semantic development of hiisi must have been the same among the crud' as among the languages of the areas they came from. Thus the crud's substratum enables us to conclude that Ancient Karelian, and possibly even the Vepsian spoken around Ladoga and Lake Onega, included the term hiisi as a reference to a place characterised by a given function. The word cannot have been a geographical term. On the other hand, however, present day eastern Finnic languages (including to some eastern Finnish dialects) reveal that the word probably did not have the same general meaning of cult place as it did in Estonian. The word must have had a more specific definition, one which no longer applies in places bearing this name. The specific function of the "hiisi" site may have been worship of the dead in some form, but there is no evidence to show that the "hiisi" sites in these areas were once burial grounds. Mythological accounts relate that the place is known for its strange happenings, or that an evil spirit lives there, or that the place generally inspires dread. These views are very close to those held in relation to "hiisi" sites elsewhere in Finland. ${ }^{10}$

In various parts of the northern Estonian, and in one case in the southern Estonian, regions, the definitions 'grove', 'wood', 'young copse' and 'large forest' have been sporadically recorded for the word hiis, but without possessing any mythological or other functional connotation. It is hardly likely that this represents actual semantic development

10 Apart from in certain parishes with in the eastern Finnish dialect regions and the bordering Karelian speaking areas which were formerly part of Finland, there are no surviving records of the functional or religious significance of places whose names contain the element hiisi around Ladoga and its expansion areas east of the 1323 border. In addition to bonfire sites (Harlu, Ruskeala, Kesälahti, Värtsilä) and other meeting points in the same districts, the cape of Hiidenniemi in Sortavala can be demonstrated to be a sacral place, one which women were forbidden to walk by. Another example of this may have been the hill of Hiiden mäki in Hiitola. Other places which were out of bounds to women are represented by a few "hiisi" sites in Häme and Southern Savo. This is evident because of names which contain the element nainen 'woman' along the nearby alternative routes to be taken by women (for information on the sacral quality of places forbidden to women see Vilkuna 1956). 
into a new lexical definition; rather, this is simply a selection of interpretations which have arisen after the cult function of the "hiis" site had lost its significance. These data do however reveal that a grove/wood was understood to be the most characteristic feature of the Estonian "hiis" prototype.

In contrast to the Estonian interpretations of grove/wood or large forest, the transitional areas between Finnish and Karelian, north of Ladoga, contain an interpretation of the word hiisi which occurs sporadically and reflects a different world view: 'a place far in the forest (or a vast forest) where one can lose one's way'. Indeed, a number of places whose names feature the component hiisi are located deep in forest land, but these are generally high mountains, in other words geographically easy to locate and therefore not points where one would get lost. The interpretation is based on the notion that losing one's way is caused by some supernatural power, usually called 'devil', which has led one astray. The concept of a supernatural orientation deceiver originally belonged to belief about the dead (e.g. Harva 1948, 288-295, Granberg 1935, 145; additional examples Koski 1967-70, 2, 60). Though genetically dissimilar, hiidenkätkö (-kätkö 'hiding-place') is based on an analogous world view. It relates to the condition of being lost and occurs among a fairly restricted section of the HämeSatakunta-Ostrobothnia areas. It evidently originated in this region in the sixteenth century at the earliest, clearly as a blend of the words metsänkätkö ( metsänpeitto), which means the same thing and is widespread among eastern and Ostrobothnian dialects, and hiidenväki ( $v a ̈ k i$ 'crowd' and 'power'), the first part of which refers to a postmortal underworld (manala) (Koski 1967-70, 2, 42-59).

\section{5.}

In addition to its factual meaning of cult place, the Finnish word hiisi has come to denote a supernatural entity both in terms of its reference to a place and in terms of its reference to a being. On many occasions, the significance of the place is not clearly defined, but it always relates to the external order of the supernatural. In certain lexical or other instances, when the nature of the place can be indentified, it often refers to a post-mortal world. A different kind of post-mortal world is depicted in different contexts. In particular, western Finnish prose tradition reflects the view of an otherworld situated underground, where the people of hiisi, the long since deceased, live (eg. hiidenväki). 
Often too, the otherworld where these beings reside is believed to exist on a mountain. An actual image of the otherworld as a mountain is, however, especially common in eastern Finnish and Karelian folk poetry. The understanding of the otherworld as a mountain is in fact an international phenomenon, obviously reflecting here the influence of Nordic mythology (see Pettersson 1987), and it is related to other, equally international motifs, such as the idea of a metallic central mountain, a motif which is clearly a later referent of the word hiisi than the motif of the otherworld-mountain itself. Likewise, in many poems the referent of the word hiisi is often identified or compared with mythical Pohjola. The many interpretations of Pohjola include the concept of a dwelling place of the dead situated far off in the North. Another type of otherworld described by the word hiisi is a farm with its house, windows, yard, farmer, farmer's wife, daughter and dog barking in the yard. In poems as well as in prose tradition hiisi signifies 'hell', or sometimes some other more lenient place of torment like hell.

The ontology of mountain, Pohjola or farm in relation to the semantics of the word hiisi raises certain problems, since there are no explicit descriptions of these places offered by informants, nor are there informants' explanations of the word hiisi which would be explicitly appropriate to such places. Folklorists may have come to create an ontological image of these places by comparing the mythology of various peoples, but for the folk singers who picked the word hiisi in order to evoke a particular topos, the image they had was not necessarily so clearly defined. Individual poems only enable us to conclude that the singers had a mythological, external plane in mind. It is characteristic of the structural format of folk poetry that the singer will use clichés in which the original, often faded, meaning of the words is not necessarily relevant as far as the whole of the story is concerned. Examples of such phrases are hiiden tytär/piika/neito/neiti etc., in which the latter part refers to a young woman and the first part to a mythological place. These clichés have found their way into various thematic strains of folk poetry. The cliché hiiden tytär ("Lähen hijestä kosihin" 'I am off to "hiisi" to court') denotes an eligible young girl from a supernatural place, and the variants hiiden tytär/impi, which appear in the charm of the Serpent's Creation, represent the motif of a hair fallen from the head of the maiden of the water. The referents of these word phrases are not identical. The back of the serpent in the aforementioned charm appears in one case as hiuksista hiiden neidon/immen 'from the hair of hiisi's maiden/virgin'. This particular cliché stems from the poem 
of the Creation of the Kantele, in which it refers to the origin of the strings of the kantele. The theme is based on the international tale of the Singing Bone, according to which a musical instrument is created from the parts of the body of a drowned maiden; it is therefore once again a post-mortal motif here (see Haavio 1952, 270-276, as well as on the same subject in Estonian folklore Koski 1967-70, 2, 118). Exploring the variety in meaning or reference among these examples serves no purpose, at least not from the point of view that the singer must have had a conscious idea of the exact nature of "hiisi". ${ }^{11}$

The post-mortal world as a vision of hell is easier to recognise, and this sense of the word hiisi has even been described by informants. As a result of Christianity, the concept of a post-mortal world became divided into two separate, good and evil otherworlds. Moreover, the value system of Christianity caused non-Christian concepts and words representing such concepts to acquire a negative connotation. It thus follows understandably that the word hiisi, in reference to a post-mortal world, became identified with the evil one of the two alternative meanings and concepts. The definition was not absolute, however. Alongside the sense of actual 'hell', there existed another sense, variously expressed, suggesting a somewhat more lenient version of hell. ${ }^{12}$

Both the dualism of the Christian world view and features from folk belief exist in the interpretations provided by informants. For example Hiijestä tulit noutajat sanothan ku jumalaton kuolee, hiijenväki sen

11 In one variant of the poem "Hiidestä kosinta" (Repola), the location of the courtship is transparently described Mänen Tuonelta tytärtä,/ Manalasta morsienta 'I go to Tuonela's daughter,/ to fetch a bride from Manala'. These lines are familiar with regard to their place reference among similar Ingrian poetry on the theme of Courtship in Tuonela, and the same theme also occurs in Estonian folklore, although in their entirety the poems themselves are structurally dissimilar. At all events, Finnish folklore employs this motif in many different thematic contexts.

12 Evidence of hiisi in the sense of the lenient version of hell can be seen for example in the saying Hyppää kuin Hi(i)ppa-Heikki hiiden ja helvetin väliä 'To leap like Hi(i)ppa-Heikki between hiisi and hell' (Hiippa-Heikki is a name for a devil). The expression is concentrated in the regions of northern Savo dialects and central and northern Ostrobothnian dialects, and it is clearly a blend of the saying about a devil leaping (bounding or springing) in hell, and of the view that a restless soul wanders between heaven and earth or hell (for different interpretations see Koski 1967-70, 2, 734-740). According to some sayings, there is a short distance between hell and "hiisi", but it is more common, particularly in eastern Finnish dialects and spreading as far as the more susceptible Ostrobothnian dialects and those of the Far North, for the word hisisi to be used in the same connection as the word helvetti 'hell'. 
noutaa describes how the people (power) of hiisi fetch those who die godless. The term "hiidenväki" here represents a western Finnish understanding of the beings which belong to the post-mortal world. In the folk poetry of eastern and Ostrobothnian dialects Hiisi, like helvetti, denotes an evil place consistent with a dualistic world view, but not a purely Christian one. Such a place may be, for example, where diseases originate or are conjured by spells, and where it is believed one can acquire the instruments (magic) of a destructive, supernatural power. The topographic setting of these places is often a mountain, and its ontological interpretation is 'the realm of the dead', at least in one of its basic forms. For example, Gustav Ränk (Ränk 1979) has shown how Finnish hiiden hevonen 'the horse of hiisi', and its Estonian equivalent hiie halli, represent the bringer of the plague, emerging from this sort of post-mortal world.

In present day Finnish hiisi only has a locative meaning in certain expletive expressions. Mene hiiteen! corresponds closely to Mene helvettiin! 'go to hell', but it is gentler in tone (thus it is not literally 'go to the devil' as dictionaries state). Apart from the interpretation of 'go to hell', the expression is also associated with the concept of a generally remote place. This corresponds to one interpretation in eastern dialects, which is itself linked to the eastern dialect expletive question missä hiidess $\ddot{a}$ ? 'where in hiisi?'. The related mental image of an external plane elicited this usage of the word. It stems from the same image which exists in the meanings of 'distant, dark forest where one can lose one's way' in a concrete sense, as well as to various concepts of the otherworld in an abstract sense.

'Devil' or generally some unspecified evil spirit or being is the most common meaning for the word hiisi in simple word form (or at least for most people the one which first comes to mind). In compound words like vesihiisi and metsähiisi the latter part denotes 'sprite', thus 'watersprite' and 'woodsprite', often with negative connotations. In the tales of the western Finnish dialect regions hiisi, often in the plural hiidet, refers to a giant, in accordance with the German folk tale tradition of "der riesische Teufel". Unlike Estonian, Finnish displays no evidence that hiisi refers to the kind of god or spirit to whom sacrifices are to be made. This change in definition can be explained as the result of the blurring of the original meaning while the word 
nonetheless continued to appear in various fixed phrases and place names. A semantic vacuum was created, and then filled by a definition appropriate to the context.

In Western Finland, Bronze Age barrows and other stone formations of similar appearance are called hiidenkiuas, -vare etc., in which the latter part means 'stone mound'. Some of these mounds are associated with a tale concerning the grave of former inhabitants. Other similar mounds and stone formations have existed at authenticated cult places from the Iron Age or a later period. The function of the genitive attribute hiiden was most probably to denote locality 'at the hiisi' or possibly possession 'of the institution of the hiisi'. As the "hiisi" institution was forced beyond the perimetres of the village, and several Bronze Age barrows came to be situated in the outlying country, or at least outside the habitation areas of Iron Age and Middle Age settlements, these mounds sometimes became a new "hiisi" site or its nucleus. The western Finnish folk tale motif of "der riesische Teufel" 'the devil giant' was probably adopted during the Middle Ages, and in Western Finland the 'giant' element bore the ontological emphasis. These giants were believed to represent a people living long before the arrival of Christianity. They are said to have gathered piles of stones and done battle by hurling these stones at one another. The tales even include aetiological explanations for the existence of the Iron Age stone mounds and other similar stone formations, based on the view that the giants collected piles of stones for hurling (cf. the corresponding Swedish terms jättekulor, jättekast, jäturkast). As these mounds are called hiidenkiuas, hiidenvare etc., and as after the disappearance of the "hiisi" tradition the word no longer referred to a place in broad, active usage, the terms were interpreted in such a way that the genitive attribute stood for a subject function. Thus it was believed that hiisi meant 'giant', and similarly, 'a person living before the arrival of Christianity'. Since there were several of these giants, as the tale goes, a plural initial word form hiittenkiuas emerged alongside the singular initial word hiidenkiuas. In Southwest Finland, in particular, the plural form even became more widespread than the singular one.

The origin of the name for an erratic glacial boulder hiidenkivi can be explained in the same way. The word first meant a cult boulder, the nucleus of the "hiisi" site, just as in Estonian hiiekivi. Thus it did not always specifically denote a glacial boulder, but referred rather to some other boulder or stone formation, the latter described by the plural hiidenkivet. The glacial boulder is often associated with a tale 
which relates how it was cast there by a giant.

Far from all the mounds which bear the name hiidenkiuas or all the glacial boulders called hiidenkivi have been sacral objects. These words have become profane terms (note present day Finnish hiidenkivi = 'glacial boulder', but the morphologically identical hiiekivi in Estonian = 'cult stone'). Names like Hiidensilta 'a row of stones in the sea or in a lake, which is said to have been made by a giant', have never denoted a sacral place. The initial part of the word referred to a giant from the term's inception. The earliest literary record of hiisi in the sense of 'giant' dates from the 1642 translation of the Bible.

Although the 'giant' element was emphasised in certain areas of Western Finland, the motif of "der riesische Teufel" has become confused with the "Zwerg" concept as in Germany and Scandinavia (e.g. collectivity, cf. Finnish hiidenväki 'the people of hiisi'). The word hiisi has consequently been used to signify not only a giant, but also other supernatural beings, often mountain spirits (where "hiisi" lives on a mountain), which are identified with the devil.

The 'demon' element is more clearly underlined in the understanding of the 'being' among the eastern Finnish dialect and Karelian language regions, where hiisi, in the sense of mythological place, was also more emphatically equated with the concept of hell than in western Finnish dialect regions. By contrast, the view that "hiidet" (plural) represents a people living before the arrival of Christianity is missing from the eastern regions, at least in an explicit sense. Several eastern Finnish places with names containing the element hiisi are associated with beliefs about a devil who lived there, and this is evidence of the same kind of reinterpretation as in western dialects.

Similar methods of reinterpretation have influenced folk poetry clichés, particularly those in which the word appears in the genitive form hiiden. These referred primarily to the realm of the dead, or later to hell, and this definition was reinterpreted to mean the ruler of the post-mortal world, or the devil in the 'hell' versions. This particular reinterpretation was very productive, and hiisi therefore appears more often as a direct reference to a being than to a place in verse tradition, especially in charms.

It is characteristic of both prose and verse folk tradition that there exists no single ontological being bearing a name meaning 'demon', but the term 'demon' applies to a being who appears in different functions in various themes. In addition to the rôle of ruler of hell, devil-creatures fulfil a number of rôles as evil spirits. One example is the forest-spirit/devil's rôle of controlling the game in hunting spells. 
As a general principle, if the charm introduces the word piru or lempo, which are unambiguous demon terms, some variants of the charm will introduce the word hiisi in their place. This semantic development must have taken place during the Middle Ages among eastern Finnish dialects and Karelian, since the introduction to Mikael Agricola's 1551 translation of the Book of Psalms, which includes a list of "the Karelian gods", contains the word hiisi as the name of the being governing the fortune of the hunt (as a general interpretation). The meaning 'devil' can also be dated by the expletive expression in Tver Karelian hiizi händäh tiedäy 'may the devil know it' (there is no evidence of the word hiisi denoting place in Tver Karelian). The comparable Finnish expression hiisi vieköön 'may the devil take it' is widespread even today. Hiisi also appears in the sense of devil in the Finnish dialect of Värmland.

The semantic imprecision of the Finnish word hiisi in users' interpretations is also demonstrated by the definition 'a dam of slush or broken ice in a waterfall', which occurs among Häme dialects. The development of this meaning may be explained as follows: The motif of 'the watersprite's herd' (Swedish 'vitterkor'), a supernatural herd rising out of land or water onto the shore, is described in Häme by the term hiiden karja 'the herd of hiisi'. Hiisi refers here to an external, supernatural plane, in the same way as in the term hiidenväki, but it is not explicitly related to the realm of the dead. Apart from the watersprite, "hiisi" is also mentioned driving the herd (genitive hiiden is felt to mean a being, demonstrating possession). A secondary feature of the motif is that "hiisi" also drives its herd through a waterfall. In a concentrated area of Häme the spirit or being "hiisi" is understood to be permanently situated in the waterfall. During the winter, when the efficiency of the mill is hampered by a dam of slush forming at the waterfall, the impediment is believed to have been created by "hiisi": hiisi pirättää veten niettei laske myllyjä pyäriin 'hiisi holds the water back to stop the mill from working', and hiisi on koskessa 'hiisi is in the waterfall'. These frequently repeated phrases have undergone reinterpretation, so that hiisi is believed to refer to the substance itself, the slush or ice, which is preventing the mill from functioning. In terms of case grammar we can say that a reinterpretation has occurred by 
which the original understanding of a causal agent has been transformed into one of an instrumental agent. It should be noted that both interpretations are possible within the same dialect, although idiolectal differences may occur. The interpretation of a genitive form originally indicating place, as a reference to a being, stems from similar deep case transformation (locative $\rightarrow$ agent/dative). Again, either interpretation may apply within the same language community (e.g. recorded data from Kymi: hiisi 'devil' and its 'place of residence').

The agent $\rightarrow$ object transition based on deep case reinterpretation also occurs in those instances where hiisi originally referred to a devil causing disease, and then came to be understood to mean the disease itself. Similar data exist in various dialect regions in Finland. They always appear sporadically, even though a certain amount of lexicalisation can be discerned. A precondition of this phenomenon is that in these same dialects hiisi also means a supernatural, evil being.

In general, the changes in meaning of the word hiisi are either deep case transformations based on syntactical reinterpretation or intentional variations within the deep case framework. The latter is illustrated, for example, by the fact that the definition of an actual cult place developed to mean the realm of the dead.

\section{8}

In conclusion, it is possible to state that the word hiisi appeared during the late Iron Age in the sense of 'cult place where the dead, the spirits of the ancestors, were worshipped' in at least the following languages: northern Estonian, western Finnish dialects in the areas of Southern Finland which were populated at that time, and apparently also western Votian. There is a certain amount of likelihood that an even earlier meaning was 'burial ground', since many "hiisi" sites in Northern Estonia and Western Finland are ancient burial grounds. However, it seems that by the end of the Iron Age it was no longer necessarily an ancient burial place which was chosen as the site for the "hiisi" cult, since not all the "hiisi" sites among prehistoric settlements are burial grounds. Later, during the Middle Ages, cults other than the cult of the dead came to be practised at the 'hiisi' sites. The centricity of the cult of the dead in ancient times is illustrated by the fact that all locative meanings relating to a supernatural world view are a variation of the concept of the realm of the dead. One might argue that 'realm of the dead' is the primary definition and 'cult place 
of the dead' the secondary, but this speculation can be refuted on the grounds that no other term for the realm of the dead (tuonela, manala) developed into a term for a cult place, nor do they appear with the same frequency in place names. In Finland, hiisi in the sense of 'cult place' has spread as far as the western side of the border established by the Treaty of Nöteborg in 1323 .

The frequent incidence of the word hiisi in place names as well as in both verse and prose folk tradition reveals that it was also familiar in Ancient Karelian in the region south of Ladoga and in its expansion areas, and possibly also at an early stage among the northern and central Vepsian dialects. There are no clear indications that the word meant 'cult place' or 'burial place' among the eastern languages (including the eastern Finnish dialects east of the 1323 border). However, the folk poetry of these areas demonstrates that some element of belief about the dead was included in the meaning. Moreover, a number of factors suggest that the definition of the word could not have been crucially different from its definition in Finland and Estonia, such as its frequent occurrence in the place names of languages descended from Ancient Karelian (including the surviving substratum of the zavoločeskaya čud'), and the partial similarity in the topographic features of the sites themselves. Thus we may infer that even in Ancient Karelian and its transitional areas hiisi referred to a cult place of the dead, though not of course necessarily a burial place. We can speculate that the word was carried from the southwestern parts of Finland and the north-western parts of Estonia up to the Ladoga regions around the time when the sense of 'burial place' was no longer current throughout all the western areas. The lack of data concerning cult places may be due to the fact that in the sphere of influence of the Orthodox church, worship of the dead took place at graveyards which were still in use and owned by the church. Thus the cult function no longer applied to the "hiisi" sites. In the western areas, which came under the influence of Catholicism, this kind of worship of the dead would not have been permitted by the church.

\section{9}

Various etymologies have been suggested for the Finnic word hiisi (see Koski 1967-70, 2, 240-248). Several of these are felt to be extremely unlikely if not impossible (e.g. the Uralic etymology. (see SKES 195581; Häkkinen 1983, 282). Those worthy of consideration are outlined below. 
There are two proposed equivalents in Lapp in the words sii'd 'dwelling place', 'nomadic village', 'mountain camp', 'nomadic group', and siei'de (Swedish Lapp seite, Inari Lapp seidi; as a loan word in Finnish seita) 'rock or stone which has been an object of worship', 'sacrificial stone', 'sacral stone understood to be an image of god', sometimes also 'wooden image of god', and personified 'god or spirit residing at the place in question' (sometimes the word also refers to a sacral rock wall, mountain fell or island), in Kildin Lapp also 'devil', 'witch'. Knut Bergsland (Bergsland 1964) has suggested that both the Lapp words and Finnic hiisi may have a common etymology. SKES 1955-81, 4 does not even mention this possibility with regard to seita, which implies a notion of its implausibility. It would presuppose that early Proto-Finnic contained a variant pair ${ }^{*} \check{s} e j+t a /{ }^{*} \check{s} e j+t e$ derived from * seje such that $-a /-e$ "probably stems from a prehistoric change in word final ${ }^{*} a, *^{*}>{ }^{*} e^{*}$. Bergsland explains the unusual first syllable vowel combination in the Lapp word sii $^{\prime} d \hat{a}$ by comparison with the sporadic sound change $i e>i$ in Lapp. In other words, an earlier form would have been *sieidă $\left(<{ }^{*}\right.$ šejte), in which case it would be etymologically linked to the word siei'de. The variant ${ }^{*}$ sej $j+t e$ would have led to Finnic hiite (:hiisi) and lapp sii'da (in Lapp $e \gg a$ ), meaning 'nomadic village'. The variant *sej+ta would have led to Finnic hii(t)ta > hitta and Lapp siei'de, meaning 'cult place'. The hypothetical, historical sound conditions on which Bergsland's theory is based overlooks two essential points: there is no actual evidence to support the hypothetical history of the words in question, and evidence of these phonological aspects in other vocabulary is questionable or extremely minimal. ${ }^{13}$

13 For examples of the final vowel stem variation $a / e$, which are not at all applicable to the word hiisi see Itkonen 1977; Korhonen 1981, 110; for secondary types $A>e$ see for example Kettunen 1955, $263 \mathrm{f}$.). The suffixal examples in Bergsland as well as certain other suffixal and suffix-boundary examples do not actually apply to the word hiisi (cf. Itkonen 1968; Itkonen 1977). First syllable ei/ii is possible in principle but extremely rare; there is no evidence of this kind of alternation in the word hiisi at the Finnic level. North Lapp giei'bme 'mating season' and Finnic kiima 'heat' (in the sense on mating) may be one example of this (see also Sammallahti 1988; or UEW 1986-88 with regard to ${ }^{*} k e j e^{2}$ ), as well as Finnish liitäa 'to glide' and leija 'kite' (cf. also leijua 'to hover'), but kiitää 'to fly' and keino 'means, method' are not semantically compatible, neither are siipi 'wing' and seipi 'dace' (type of fish) (for the etymology of the latter see Nuutinen 1987). Erkki Itkonen (Itkonen 1976,8) says: "Die alte Etymologie eine Zusammenstellung von lappisch siei'de mit ostseefinnisch hiisi - - wäre nur durch die Annahme möglich, dass sich der Vokalismus des Wortes a uf einer der beiden Seiten z.B. aus Affektgründen ganz 
The hypothesis that Lapp siei'de is related to Finnic hiisi is an attractive one since there is a certain semantic compatibility between the words, but there is also an essential difference in the characters of the referents: "siei'de" is the object of worship itself, a kind of deity, not a place, as "hiisi" is. Furthermore there is no evidence that "siei'de" ever related to the cult of the dead (see Itkonen 1945; Itkonen 1976, $7 \mathrm{ff}$;; Vorren 1987). Demonstrating historical phonological congruity raises problems by contrast, since relationship, even between the Lapp words, is not considered likely. The word sii'd $\hat{a}$ 'nomadic village' would at least be phonologically closer to the word hiisi (especially if one ignores its presumed earlier form of *siejda), but the connection is extremely doubtful from a semantic point of view. The most likely assumption we could make would be that the word originally bore the predominant semantic idiom of 'an external place (or possibly collective)', which would then have narrowed its meaning to 'natural, profane place' in Lapp and 'supernatural, sacral place' in Finnic.

Even if one or both Lapp words and Finnic hiisi did reveal a common origin, their etymology would even then not be straightforward. The question would still remain of how and from where the word entered early Proto-Finnic.

Tette Hofstra (Hofstra 1988) has taken the word hiisi to be a Germanic loan, from Germ. * sidōn 'side' also 'shore' (commonly connected with Germ. *sidaz 'extending lengthways', 'long', 'deep', 'low') < IE root *seit-. A according to Trier 1951, 41 and Vries 1962, 472 *sei 'weave' so that in the meaning 'side' a weaved wall is the point of departure. It has been suggested that ${ }^{*}$ se $i$ would be a basic root even for the Old Norse sida 'to work magic' < Germ. *sipan < *seipan; the Old Norse seidr 'witchcraft' < Germ. ${ }^{*}$ saibaz < IE *soitos (IE ${ }^{*}$ seit-/*soit-/* ${ }^{*}$ sit-. ${ }^{14}$ The difficulty with this etymology lies in se-

exzeptionell entwickelt hätte." The sound changes caused by the affectivity of the word are nevertheless of a different kind, and they do not apply to terms like the words in question. With even greater reservation Bergsland associates hiisi with the word hi(i)ppa, which denotes some sort of play and appears in connection with a supernatural being in folklore. Bergsland has interpreted 'play' to indicate 'dance' and concludes that hiippa derives from the participle *heitpa $\left(<{ }^{*} \check{s} e i+p a\right)$ 'dancing' and *seitta/te 'object of, or place for, cult dancing'. The word hi(i)ppa, which has no connection with dance, can be demonstrated to derive from a medieval name for a saint (see Haavio 1947, 14--22). Bergsland does indeed mention this, and it is therefore inconsistent of him to suggest a relationship with early Proto-Finnic. Bergsland's proposal that the Lapp words may have been borrowed from Finnish is hardly likely, since in that case they should have the word initial $h$.

14 The connection between the Old Norse seiðr and lapp siei'de was made at an 
mantics. Hofstra presumes that from the semantic point of view the existence of a topographic meaning as such suffices to an etymological relation, but the conceptual link between 'side' and the "hiisi" sites is extremely improbable. Even the conceptual connection between the magic and the "hiisi" cult is unclear.

Finnic hiisi has also been associated with a Scandinavian word (Tunkelo 1914), which is represented in Swedish by the word (h)ide Old Swedish hipe $<$ hiði $<$ hidija (Proto-Scandinavian $j$ derivative, from the Indo-European root *kei- 'to lie/rest', the substantive derivative of which originally meant 'resting place' (Hellquist 1964; Grønvik 1990). The basic definition in all the Nordic languages is 'winter lair', and in Swedish dialects (especially Småland, Skåne) also 'stoney, invious place', and often together with this 'tangled thicket', also 'stone mound' (Västergötland) 'dense, young copse' (also in Hjärne's texts dating from 1715; SAOB 1898-). In various Swedish dialects the word also denotes a place with a generally bad reputation, often a criminals' hide-out, and it occurs frequently in place names, particularly names of houses (SAOB 1898-; Koski 1967-70, 2, $246 \mathrm{f}$. using as primary sources ULMA (Dialekt- och folkminnesarkivet i Uppsala), SOA (Svenska Ortnamnsarkivet, Uppsala) and a manuscript of B. Holmberg, Göteborg). In one runic inscription the word is used to refer to a human burial place in a context which indicates sacral behaviour or sacrifice (Grønvik 1990). The sense of 'winter lair' is elicited by the word's primary meaning of 'to lie/rest'. In general the word seems to have a distinctly negative ('bad') connotation in present day language. The definitions of a topographic nature, as well as the word's frequent appearance in place names indicate that 'winter lair' has to some extent been a recessive meaning.

The topographic features of "(h)ide" sites correspond to those of prototypical "hiisi" sites. There is a common functional semantic element in 'place to lie/rest' in the sense that it provides a point of association: a person lying in a grave resembles an animal hibernating in its nest. Grønvik demonstrates that this can be a metaphorical usage of the word, and a lexical development based on the same metaphor may have resulted in Finnic hiisi 'burial place' > 'cult place'. The loan may be connected with a specific type of burial ground of Scandinavian origin. Certain lines of folklore seem to imply funeral

early stage by Castrén and Friis (see Collinder 1953, 162, 171; Bergsland 1964, 245). Hofstra works on the assumption that the substitution $s>\check{s}$ took place during early proto-Finnic, since other examples of this have been found. 
pyres, but in general this cannot be considered to be a reliable method of dating the word. The distribution of the word hiisi confirms the notion of a Scandinavian loan rather than that of an origin in ProtoFinnic. The Iron Age nucleus is located amid the western areas around the Gulf of Finland, and the word may have travelled from here along the eastern route of the Varangians as far as the Ladoga region. Both vocabulary and other cultural phenomena suggest this distribution, particularly the trajectory from Western Finland and Häme as far as the Vepsian regions (see e.g. Itkonen 1983; Vahtola 1987).

The Scandinavian etymology of hiisi is usually refuted on phonological grounds. It would be easier to imagine an $i$-stem hiiti, but nonetheless a number of other Scandinavian and Old Swedish loans which conform to the $e$-stem have been discovered (e.g. piki, kimpi, peitsi, tiili, see Hahmo 1986). However, assibilation $t i>$ si cannot be demonstrated within these strata of loans. Thus it would be acceptable to consider an oblique case vowel stem hiitet: hiibet and nominative singular hiiti, derived from Scandinavian hipi, but not hiisi (also the plural stem), because assibilation has been proven to be a later sound change (approximately $1000 \mathrm{BC}$ ). Absolute adoption of the analogical $e$-stem model would however presuppose a nominative form hiisi (as in vesi:vete+), since assibilation is a feature of $e$-stem words. Besides the common $i$-stem nors $(s) i$ : nors $(s) i+(<$ Swedish nors, 'smelt $=$ Osmerus') there is in Finnish a dialectal variant norsi: norret (:'norte+) which shows that people observe the model of the assibilated $e$-stem (SKES 1951-81; Hahmo 1986, 169). ${ }^{15}$ However, there is a certain $t / s$ indeterminateness present in the word hiisi which never occurs in original $e$-stem words, for example the apocope hiit in initial position suggesting nominative form, which occurs in place names, and the sporadic hiid: hiie paradigm in Estonian, and the hiiti:hiiti+ paradigm in Finnish (which can have the function of a derivative in certain cases). This indeterminateness would suggest that hiisi had not yet emerged in Proto-Finnic. Evidence of parallel development is one of the fundaments of etymological analysis. We therefore require a comparable type of Scandinavian loan, which would have adapted to Finnic $e$ stems, and in which $t$ would precede final $i$ enabling assibilation to take place, in keeping with the conditions of the Finnish language. There does not seem to be any evidence of this type among the few $e$-stems which do exist. The absence of a parallel example nonetheless fails to

15 For the unconditional and conditional circumstances of assibilation in present day Finnish see Koski 1979. 
confirm that the principle of complete analogical levelling cannot have applied to a Scandinavian loan.

The etymology of the Finnic word hiisi is thus not entirely unambiguous. It is tempting to associate hiisi with the Lapp word siei'de, but phonological criteria prevent this from being a fully acceptable proposition. The Lapp word $s i i^{\prime} d \hat{a}$ may be phonologically closer to hiisi, but not unreservedly so, and the semantic compatibility is questionable. Association with either Lapp word still fails to elucidate the etymological origin of the word. The connection with the Germanic words meaning 'side' and 'to work magic' is semantically doubtful. The Scandinavian etymology seems to be appropriate from the point of view of semantics and linguistic geography ${ }^{16}$, and, in addition, the phonological uncertainty (assibilation) remains no more than an assumption.

\section{Bibliography}

Bergsland, K. 1964. Suomen hiisi. Virittäjä. Helsinki.

Collinder, B. 1953. Lapparna. Stockholm.

Granberg, G. 1935. Skogsraiet i yngre nordisk folktradition. Uppsala.

Grønvik, O. 1990. Der Runenstein von Tanum - ein religionsgeschichtlisches Denkmal aus urnordischer Zeit. Old Norse and Finnish religion and cultic place-names. Ed. by T. Ahlbäck. (Scripta Instituti Donneriani Aboensis 13.) Ảbo.

Haavio, M. 1947. Das Renntierlied des Mihkaili Shemeikka. Journal de la Société Finno-Ougrienne 53. Helsinki

- 1952. Kirjokansi. Porvoo.

- 1959. Karjalan jumalat. Porvoo.

- 1961. Kuolematonten lehdot. Porvoo.

Hahmo, S.-L. 1986. Zweisilbige ostseefinnische Nominalstämme auf - $e$ im Lichte der Lehnwörter. (Soviet finno-ugric studies 22, 3.) Tallinn.

Harva, U. 1948. Suomalaisten muinaisusko. Porvoo.

Hellquist, E. 1964. Svensk etymologisk ordbok. Lund.

16 There are a lot of Scandinavian (or late Germanic) and old Swedish loans which are common to Finnish, Karelian, Ingrian and Estonian (a number of these appear only in the northern dialects but are not restricted merely to the northeast coast, which is prone to Finnish influence; a number of them appear in the southern dialects as well); some of these words are also known in Lydian, northern or central Vepsian and in Votian; eg. haalata, halti(j)a, joulu, kari, kelkka, keppi (also in Livian), lato, lauantai/laukopäivä, letti, lievä, liippa (also in Livian), lohi(käärme) (SKES 1955-81; KKS 1968-83; Nirvi 1971; VMS 1982; Zaitseva \& Mullonen 1972). 
Hofstra, T. 1988. Hiisi: Uusi ehdotus sen germaanisesta alkuperästä. Omaa vai lainattua. Itämerensuomen germaanisiin lainasanoih in liittyviä kirjoitelmia 1. [Ed. by] S.-L. Hahmo et al. (Suomi 143.) Helsinki.

Häkkinen, K. 1983. Suomen kielen vanhimmasta sanastosta ja sen tutkimisesta. (Publications of the Department of Finnish and General Linguistics of the University of Turku 17.) Turku.

Itkonen, E. 1976. Älteste Elemente der lappischen Volksüberlieferung. Journal de la Société Finno-Ougrienne 53. Helsinki.

- 1977. Die Umwandlung einiger $a$ - und $\ddot{a}$-Stämme zu $e$-Stämmen im Urfinnischen. Journal de la Société Finno-Ougrienne 75. Helsinki.

Itkonen, T. 1968. Einige Fragen der urfinnischen Laut- und Formengeschichte. Congressus secundus internationalis fenno-ugristarum 1 . Helsinki.

- 1971. Aunuksen äänneopin erikoispiirteet ja aunukselaismurteiden synty. Virittäjä. Helsinki.

- 1983. Välikatsaus suomen kielen juuriin. Virittäjä 2-3. Helsinki.

Itkonen, T. I. 1945. Suomen lappalaisten muinaisuskosta. Kalevalaseuran vuosikirja 23-24. Porvoo.

Kettunen, L. 1955. Etymologische Untersuchung über estnische Ortsnamen. (Annales Academiae Scientiarum Fennicae B, 90, 1.) Helsinki.

KKS Karjalan kielen sanakirja 1-3. 1968-83. (Lexica Societatis FennoUgricae 16, 1-3.) Helsinki.

Korhonen, M. 1981. Johdatus lapin kielen historiaan. (Suomalaisen Kirjallisuuden Seuran toimituksia 370.) Helsinki.

Koski, M. 1967-70. Itämerensuomalaisten kielten hiisi-sanue 1-2. (Annales Universitatis Turkuensis C, 5, 7.) Turku.

- 1977. The change of semantic structure in some Balto-Finnic place names. Onoma 21, 1-2. Louvain.

- 1979. Nykysuomen assibilaatio. Virittäjä. Helsinki.

Laanest, A. 1982. Einführung in die ostseefinnischen Sprachen. Hamburg.

Matveyev 1976 = Матвеев, А. К. Топонимические этимологии VII. Советское Финно-угроведение XII : 3 . Таллин.

Nirvi, R.E. 1971. Inkeroismurteiden sanakirja. (Lexica Societatis FennoUgricae 18.) Helsinki.

Nissilä, V. 1967. Die Dorfnamen des alten lüdischen Gebietes. (Mémoires de la Société Finno-Ougrienne 144.) Helsinki.

Nuutinen, O. 1987. Kalannimi seipi. Fennistica festiva in honorem Göran Karlsson septuagenarii. (Fennistica 9.) Åbo.

Pettersson, O. 1987. Old Nordic and Christian elements in Saami ideas about the realm of the dead. Saami religion. Ed. by T. Ahlbäck. (Scripta Instituti Donneriani Aboensis 12.) Åbo.

PK 1930. = Писцовые книги обонежской пятины 1496 и 1563 гг. 1930. Ленинград.

Ränk, G. 1979. Hiiehobune. Eesti Teadusliku Seltsi Rootsis aastaraamat 8. Stockholm. 
Saareste, A. 1959. Eesti keele mõisteline sõnaraamat 2. Stockholm.

Sammallahti, P. 1988. Historical phonology of the Uralic language with special reference to Samoyed, Ugric and Permic. Handbook of Uralic studies. Ed. by D. Sinor. (Forthcoming.)

SAOB Svenska Akademiens ordbok över svenska språket. 1898- [Ed. by] Svenska Akademien. Stockholm.

Tallgren, A. M. 1933. Hiisi ja Moisio. Virittäjä. Helsinki.

SKES Toivonen, Y. H. et al. 1955-81. Suomen kielen etymologinen sanakirja 1-7. (Lexica Societatis Fenno-Ugricae 12, 1-7.) Helsinki.

Trier, J. 1951. Lehm, Etymologien zum Fachwerk. Marburg.

Tunkelo, E. A. 1914. Eräistä vainajainpalvontaan liittyvistä suomalaisista nimityksistä. Kansatieteellisiä tutkielmia, omistettu Kaarle Krohnille. (Mémoires de la Société Finno-Ougrienne 35.) Helsinki.

UEW Redei, K. 1986-88. Uralisches etymologisches Wörterbuch 1-5. Budapest.

Vahtola, J. 1987. Vanhojen kansanrunojen nimistön ja todellisen nimistön välisistä yhteyksistä. Muinaisrunot ja todellisuus. [Ed. by] M. Linna. (Historian aitta 20.) Jyväskylä.

VKM Vatjan kielen Kukkosin murteen sanakirja. 1980. [Ed. by] L. Posti \& S. Suhonen. (Lexica Societatis Fenno-Ugricae 19.) Helsinki.

Vilkuna, A. 1956. Das Verhalten der Finnen in "heiligen" (pyhä) Situationen. (FF Communications 164.) Helsinki.

Vorren, $\varnothing .1987$. Sacrificial sites, types and function. Saami religion. Ed. by T. Ahlbäck. (Scripta Instituti Donneriani Aboensis 12.) Åbo.

Vries, J. de 1962. Altnordisches etymologisches Wörterbuch. Leiden.

VMS Väike murdesõnatik 1. 1982. [Ed. by] V. Pall. Tallinn.

Zaitseva \& Mullonen $1972=$ М. И. Зайтсева - М. И. Муллонен. Словарь вепсского языка. Ленинград. 